DOI: 10.46340/eppd.2020.7.6.7

\author{
Mykhailo Okhendovskyi \\ ORCID ID: https://orcid.org/0000-0002-7357-7607 \\ Taras Shevchenko National University of Kyiv, Ukraine
}

\title{
ATYPICAL SOURCES OF INTERNATIONAL ELECTION STANDARDS AND THE PROBLEMS OF THEIR OBLIGATORINESS FOR MEMBER STATES OF THE INTERNATIONAL AND REGIONAL COMMUNITIES
}

\author{
Михайло Охендовський \\ Київський національний університет імені Тараса Шевченка

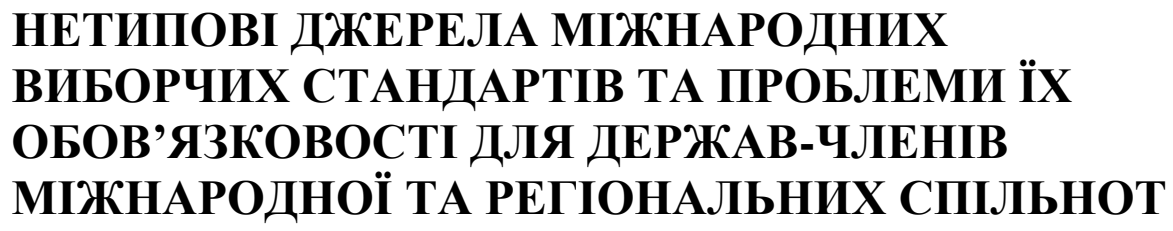

The article deals with the role of atypical sources of international election standards and the problems of their binding force for member states of the international and regional communities, in particular on the example of the Venice Commission. The issues of legal nature, legal force are covered, as well as the nature and scope of documents adopted by non-statutory bodies of international intergovernmental organizations and international non-governmental organizations. The author provides ways to legalize such acts, including: binding the decisions of non-statutory bodies of the international intergovernmental organizations; legalization of the non-statutory body of international intergovernmental organizations; gradual legalization of the non-statutory body or its decisions.

Keywords: electoral law, electoral legislation, international election standards, legal nature of international election standards, international organizations.

Постановка проблеми. Питання легалізації, легітимації міжнародних виборчих стандартів, що закріплені в міжнародних міждержавних договорах та прийняті державами в рамках міжнародних міжурядових організацій (далі - ММУО) і підлягають обов'язковому виконанню як їх міжнародноправові зобов'язання і одночасно норми національного права, у більшості аспектів практично не викликають зауваження, то прийняття нормативних актів різними нестатутними органами ММУО та міжнародними неурядовими організаціями (далі - МНУО) викликають питання щодо їх правової природи, юридичної сили й, звичайно, щодо обов'язковості їх виконання державами, що є членами міжнародної та регіональних спільнот.

Крім того, у наявності існує проблема виконання державами рішень органів ММУО, що приймаються їх статутними органами. Але тут вже існує усталена практика, що заснована на визнанні того факту, що якщо держава є членом відповідної ММУО, то вона бере на себе обов'язок щодо виконання всіх іiі рішень, в тому числі й рішень, що приймають допоміжні органи такої ММУО, що створені відповідно до ії статуту.

Але, незалежно від того, тут існує проблема, що знаходить відповідний вираз у дефектності міжнародної правосуб'єктності як самої ММУО, так й держав, що є ії членами, бо при створені ММУО всі їх права і можливості, по великому рахунку, закріплюються в їх статутному документі, що й визначає їх міжнародну правосуб'єктність. Якщо статутний орган ММУО приймає відповідне рішення у вигляді відповідного міжнародного акту, то виникає кореспондуючий обов'язок державичлена цієї організації щодо виконання цього рішення. Однак тут на практиці може виникнути два шляхи для вирішення цієї проблеми: перший - коли держава-член ММУО відмовляє у виконанні 
такого рішення статутного органу ММУО, посилаючись на те, що він вийшов за рамки статутної правосуб'єктності ММУО; другий - коли держава виконує таке рішення, що зафіксоване в міжнародному акті та мовчазно визнає факт як міжнародної правосуб'єктності статутного органу ММУО, так й факт довільного розширення міжнародної правосуб'єктності самої ММУО і таким чином сприяє формуванню такої нової, розширеної іiі правосуб'єктності, що не була раніше закріплена в іiі статутному документі. Таким чином, йде процес розширення об'єктної бази міжнародно-правового регулювання конкретної ММУО і фактично відносно цього формується міжнародний звичай, бо право ММУО регулювати відповідні питання, які вона або її статутні органи вже почали регулювати фактично самостійно, у явочному порядку, не є передбаченим статутними документами ММУО.

При виникненні питання про виконання рішень державами, що прийняті позастатутними органами ММУО, членами якої вони $є$ та які створюються самими ММУО для полегшення їх роботи або спеціалізації у відповідних напрямках їх статутної діяльності, що мають консультативний або інший статус - його вирішення повністю залежить від волевиявлення держави-члена. Саме вона має прийняти рішення про виконання або невиконання міжнародного акта, який прийнятий позастатутним органом ММУО. Однак тут виникає відповідна проблема морально-етичного характеру: якщо держава $€$ членом відповідної ММУО, то це означає, що вона визнає ії особливу роль та значення у міжнародній системі саме в вирішенні відповідного профільного кола проблем, що представляють особливий інтерес для членів міжнародної спільноти та мають велике значення для співробітництва держав у відповідній профільній сфері - у нашому випадку в сфері прав людини щодо виконання іiі політичних прав у виборчому процесі. Звідсіля держава-член довіряє відповідній ММУО, яка має відповідний міжнародний авторитет, вирішувати коло проблем, що входять до ії статутних завдань. Тому держава може вільно і усвідомлено піти на визнання рішень позастатутних органів такої ММУО, формуючи спочатку міжнародний звичай, а потім, після визнання більшістю членами ММУО правосуб'єктності таких позастатутних органів - й відповідні міжнародні норми, що будуть закріплювати часткову, фрагментарну, функціональну міжнародну правосуб'єктність таких позастатутних органів.

Відтак, метою статті $\epsilon$ визначення особливостей нетипових джерел міжнародних виборчих стандартів та проблеми їх обов'язковості для держав-членів міжнародної та регіональних спільнот.

Результати дослідження. При виникненні питання щодо виконання державами-членами міжнародної і регіональних спільнот рішень, що прийняті МНУО, тобто інституціями міжнародного громадянського суспільства, слід зазначити те, що хоча й такі рішення можуть бути прийнятими в межах міжнародно-правових зобов'язань держави, що були взяті в рамках $\mathrm{OOH}$ або ММУО чи розвивають такі зобов'язання - у держав не виникає обов'язку щодо їх виконання і таке виконання може мати добровільний характер, спираючись на повагу держави до позиції міжнародної громадськості. Але тут є один важливий момент - якщо держава дає згоду на виконання таких рішень та закріплює їх відповідним чином у вигляді відповідного обов'язку держави - то остання легалізує такі зобов'язання шляхом їх нормативізації у національному законодавстві. Якщо кількість держав, що пішли таким шляхом $є$ значною, то може розпочатися процес міжнародної правотворчості, що піде декількома шляхами: а) держави-підписанти таких рішень МНУО в рамках ММУО можуть дійти висновку про необхідність їх трансформації у міжнародно-правові зобов'язання держав шляхом відповідного доповнення багатосторонніх угод або прийняття нової угоди; б) одна 3 державпідписантів може виступити з ініціативою про необхідність розробки спеціальної міжнародної конвенції, що легітимує рішення МНУО; в) з такою ініціативою виступає ММУО.

Однак, в даний час, у зв'язку з глобалізацією міжнародної системи та міжнародної спільноти держав відбувається одночасно посиленням ролі міжнародних організацій на міжнародній арені, зазначені аспекти діяльності розглянутих організацій потребують переосмислення i, найчастіше, нового аналізу.

Вважаємо, що держава, вступаючи в будь-яку ММУО, по-перше, бере на себе зобов'язання тільки в рамках його установчого (статутного) акту, що визначає міжнародну правосуб'єктність конкретної ММУО, а, по-друге, якщо тлумачити положення такого установчого акту, то для держави $\epsilon$ обов'язковими тільки рішення статутних органів ММУО. Дійсно, держава може визнавати рішення нестатутних (допоміжних) органів ММУО, що були створенні з метою вирішення конкретних актуальних проблем та $є$ допоміжними органами таких організацій. Але таке визнання функціонує 
не на рівні зобов'язання держави, що вона брала на себе в рамках установчого акту ММУО, а на рівні міжнародного звичаю, який формально не зобов'язує державу до обов'язкового виконання. Разом 3 тим, враховуючи досить частий характер виникнення такого питання, його можна вирішити завдяки відповідних організаційно-правових дій статутних органів ММУО трьома шляхами:

a) надання відповідної обов'язковості рішенням нестатутних органів ММУО, виходячи з їх особливої важливості, що були ними прийняти в межах їх функціональної компетенції, шляхом наступної легалізації статутними органами самої ММУО;

б) надання легалізації самому нестатутному органу ММУО, шляхом одночасної трансформації його правового статусу з нестатутного в статутний орган ММУО (внесення змін до статуту організаціi);

в) поступової легалізації самого нестатутного органу чи його рішень завдяки надання йому відповідних профільних завдань, що формують його функціональну (часткову, фрагментарну) міжнародну правосуб'єктність.

В контексті здійсненого дослідження вважаємо за необхідне аналіз діяльності такої міжнародної організації як Європейської комісії за демократію через право (Венеціанської комісії (далі - ВК).

Свропейська комісія за демократію через право - більш відома як Венеціанська комісія, оскільки засідає у Венеції- $є$ дорадчим органом Ради Європи 3 конституційних питань. Роль Венеціанської комісії полягає у наданні юридичних консультацій своїм державам-членам i, зокрема, у наданні допомоги державам, які бажають привести свої правові та інституційні структури у відповідність до європейських стандартів та міжнародного досвіду в галузі демократії, прав людини та правління права. Вона також допомагає забезпечити розповсюдження та консолідацію спільної конституційної спадщини, відіграючи унікальну роль уврегулюванні конфліктів, та надає "надзвичайну конституційну допомогу" державам, що перебувають у перехідному періоді.

Комісія налічує 62 держави-члени: 47 держав-членів Ради Свропи та 15 інших країн (Алжир, Бразилія, Канада, Чилі, Коста-Ріка, Ізраїль, Казахстан, Республіка Корея, Косово, Киргизстан, Марокко, Мексика, Перу, Туніс та США). Аргентина, Японія, Сен-Осада та Уругвай є спостерігачами, Білорусь має статус асоційованої держави-члена. Південноафриканська Республіка та Палестинська національна адміністрація мають особливий статус співпраці. Свропейська комісія та ОБСЄ / БДІПЛ беруть участь у пленарних засіданнях Комісії.

Його окремими членами $\epsilon$ викладачі публічного та міжнародного права, верховні та конституційні суди, члени національних парламентів та низка державних службовців. Вони призначаються державами-членами на чотири роки, але діють у своїй індивідуальній якості. Пан Джанні Букікчіо, Італія, є головою Комісії з грудня 2009 року.

Комісія працює у трьох напрямках ${ }^{1}$ :

- демократичні інститути та основні права;

- конституційне правосуддя та звичайне правосуддя;

- вибори, референдуми та політичні партії.

Комісія ділиться стандартами та найкращими практиками, прийнятими в країнах Ради Європи за ії межами, особливо в сусідніх країнах.

Коли у 1990 році було створено ВК - це був проект всього лише десятку держав-членів РС, що були зацікавлені в просуванні європейського конституційного надбання. На сьогодні, на думку Голови Венеціанської комісії К Дж. Букіккіо, вона «визнана невід’ємною частиною європейської конституційної архітектури і значимим партнером цілої низки неєвропейських держав. 60 країн $\epsilon$ повноправними членами Венеціанської комісії» ${ }^{2}$.

Фактично виникнення ВК стало об'єктивним процесом, що розпочався після розпаду Союзу РСР та світової системи соціалізму, коли нові демократії континенту визнали і сприйняли цінності P€ - права людини, демократичні принципи, верховенство права - i стали його повноправними членами. Однак вони явно потребували допомоги зарубіжних експертів, щоб втілити свої нові ідеали у національних конституціях і законодавчих актах. Саме в цей час ВК була здатна здійснити таку

\footnotetext{
${ }^{1}$ Устав Европейской комиссии за демократию через право, 2002 (Совет Европы). Council of Europe <https://www.venice.coe.int/WebForms/pages/default.aspx?p=01_01_Statute> (2020, листопад, 12).

${ }^{2}$ Хабриева, Т. Я., Лафитский, В. И. (ред.) (2014). Венеицанская комиссия: сто шагов к демократии через право. Москва: Статут, 9.
} 
допомогу, iі члени стали авторитетними консультантами в процесі розробки конституцій та законодавчих текстів в сфері публічного права ${ }^{1}$.

ВК практично здійснив «переворот» у сфері співробітництва держав в рамках РС, бо його завданням стали консультації та сприяння з питань, що напряму торкаються ядра державного суверенітету, а саме - розподілу влад, функціонування державних інститутів, конституційного правосуддя, організації судової влади, виборчого законодавства. Тобто вперше зазначені питання, що в основному були питаннями внутрішньодержавними стали безпосередніми об'єктами загальноєвропейського (міжнародного) регулювання в контексті запозичення позитивного конституційного досвіду та здійснення відповідної конституційної експертизи. Таким чином, ВК створює єдину систему координат в європейському конституційному законодавстві та формує i втілює в конституційну та законодавчу практику-держав членів Р€ та інших держав міжнародні правові стандарти, в тому числі й в сфері виборчого права.

Так як комісія була створена у 1990 році в рамках РС, а Статут останньої був прийнятий у 1949 році при створенні самої РС та не був змінений, ВК $є$ позастатутним органом РЄ, що створена Комітетом міністрів на основі Часткової угоди держав-членів ${ }^{2}$. Слід зазначити, що саме часткові угоди Ради Європи відіграли важливу конституюючу та інституційну роль у створенні Венеціанської комісії.

Разом з тим у доктрині міжнародного права вже $є$ перші наробітки в цьому напрямі. В їхній основі, насамперед, лежить суб'єктний факт, що створена в 1990 р. як часткова угода 18 державамичленами РЄ, в лютому 2002 р. ВК стала розширеною угодою, що дозволило ввійти в неї неєвропейським державам і стати в ній повноправними членами.

Сформувалася доктринальна позиція, відповідно до якої рекомендації ВК СС носять для держав рекомендаційний характер. Так, російський дослідник М. О. Лимоннікова відзначає, що ВК готує висновки, які містять рекомендації щодо законодавства конкретних держав, розробляє принципи і стандарти у формі керівних засад чи «зводів (кодексів) належної поведінки» (codes de bonne conduite), які «уніфікують» ту чи іншу сферу (наприклад, вибори), що використовуються законодавчими, правозастосовними й іншими органами держав, які беруть участь у роботі Комісії․ Вона ж визначає правову природу актів ВК як рекомендаційні норми, що включають у себе норми «м'якого» права ${ }^{4}$. До такого права, наприклад, можна віднести Положення про заборону і розпуск політичних партій і аналогічних заходів 1999 р., Керівні засади і звіт про фінансування політичних партій 2001 р., Звід рекомендаційних норм при проведенні виборів 2002 р., Висновок про заборону фінансування політичних партій з іноземних джерел 2006 р.

Варто зазначити, що вказані акти ВК із питань виборів і політичних партій виражають opinio juris держав, тобто сприймаються державами-членами як право ${ }^{5}$. Тому, вважаємо, що тут в наявності $\epsilon$ відповідне діалектичне та онтологічне протиріччя між рекомендаційним характером рішень та сприйняттям їх в якості права, що ще більше ускладнює і актуалізує досліджувану проблематику.

Підтвердженням нашої позиції є те, що деякі рішення і постанови Свропейського Суду по правах людини і деяких національних судів, прямо посилаються на зазначені акти ВК. 3 одного боку, інституціонального, це може свідчити про початок процесу формування звичаєвого права, а з іншого, функціонального - рішення міжнародних і національних судів фактично легалізують рекомендаційні норми ВК, надаючи їм силу обов'язкових, бо такі рішення повинні виконуватись сторонами по справі в обов'язковому порядку. Виходячи саме з цього, розроблений ВК Звід рекомендаційних норм при проведенні виборів 2002 р., маючи відповідне посилання міжнародних і національних судових інстанцій, може стати основою європейської Конвенції Ради Європи у сфері виборів ${ }^{6}$.

Висновки. Отже, можна говорити про істотну ініціюючу роль ММУО і про їх досить високий консультативний статус, свідченням якого є взаємодія як із Венеціанською Комісією, так і з БДІПЛ

\footnotetext{
${ }^{1}$ Burgess, J. P. (2002). What's so European about European Union? Legitimacy between Institution and Identity. European Journal of Social Theory, 5(4), 467-489.

2 Устав Европейской комиссии за демократию через право, 2002 (Совет Европы). Council of Europe

<https://www.venice.coe.int/WebForms/pages/default.aspx?p=01_01_Statute> (2020, листопад, 12).

3 Лимонникова, М. А. (2010). Венецианская комиссия Совета Европы: Правовые аспекты создания и деятельности: автореферат дисертаиії кандидата юридичних наук. Москва, 4.

${ }^{4}$ Там само.

${ }^{5}$ Там само.

${ }^{6}$ Там само.
} 
ОБСЄ. Разом з тим варто акцентувати увагу на тому, що рішення ММУО мають не тільки для державчленів рекомендаційний характер.

Якщо питання легалізації, легітимації міжнародних виборчих стандартів, що закріплені в міжнародних міждержавних договорах та прийняті державами в рамках ММУО і підлягають обов'язковому виконанню як їх міжнародно-правові зобов'язання і одночасно норми національного права, у більшості аспектів практично не викликають зауваження, то прийняття нормативних актів різними нестатутними органами ММУО та міжнародними неурядовими організаціями (МНУО) викликають питання щодо їх правової природи, юридичної сили й, звичайно, щодо обов'язковості їх виконання державами, що є членами міжнародної та регіональних спільнот ${ }^{1}$.

При виникненні питання про виконання рішень державами, що прийняті позастатутними органами ММУО, членами якої вони $є$ та які створюються самими ММУО для полегшення їх роботи або спеціалізації у відповідних напрямках їх статутної діяльності, що мають консультативний або інший статус - його вирішення повністю залежить від волевиявлення держави-члена.

Держава може визнавати рішення нестатутних (допоміжних) органів ММУО, що були створенні з метою вирішення конкретних актуальних проблем та $є$ допоміжними органами таких організацій - але таке визнання функціонує не на рівні зобов'язання держави, що вона брала на себе в рамках установчого акту ММУО, а на рівні міжнародного звичаю, який формально не зобов'язує державу до обов'язкового виконання. Разом з тим, враховуючи досить частий характер виникнення такого питання, його можна вирішити завдяки відповідних організаційно-правових дій статутних органів ММУО трьома шляхами: 1) надання відповідної обов'язковості рішенням нестатутних органів ММУО, виходячи з їх особливої важливості, що були ними прийняти в межах їх функціональної компетенції, шляхом наступної легалізації статутними органами самої ММУО; 2) надання легалізації самому нестатутному органу ММУО, шляхом одночасної трансформації його правового статусу з нестатутного в статутний орган ММУО (внесення змін до статуту організації); 3) поступової легалізації самого нестатутного органу чи його рішень завдяки надання йому відповідних профільних завдань, що формують його функціональну (часткову, фрагментарну) міжнародну правосуб'єктність.

\section{References:}

1. Khabriyeva, T. Ya., Lafitskiy, V. I. (ed.) (2014). Venetsianskaya komissiya: sto shagov k demokratii cherez pravo [Venice Commission: One Hundred Steps Towards Democracy Through Law]. Moscow: Statute. [in Russian].

2. Ustav Yevropeyskoy komissii za demokratiyu cherez pravo, 2002 (Sovet Yevropy) [Statute of the European Commission for Democracy through Law, 2002 (Council of Europe)]. Council of Europe $<$ https://www.venice.coe.int/WebForms/pages/default.aspx?p=01_01_Statute> (2020, November, 12). [in Russian].

3. Limonnikova, M. A. (2010). Venetsianskaya komissiya Soveta Yevropy: Pravovyye aspekty sozdaniya i deyatelnosti [Venice Commission of the Council of Europe: Legal aspects of creation and activity]: avtoreferat disertatsii kandidata yuridichnikh nauk [abstract of thesis of the candidate of jurisprudence]. Moscow. [in Russian].

4. Burgess, J. P. (2002). What's so European about European Union? Legitimacy between Institution and Identity. European Journal of Social Theory, 5(4), 467-489. [in English].

5. Snyder, F.(1993). Soft law and institutional practice in the European Community. European University Institute Working Paper, LAW. Florence, 93/5, 2. [in English].

\footnotetext{
${ }^{1}$ Snyder, F.(1993). Soft law and institutional practice in the European Community. European University Institute Working Paper, LAW. Florence, 93/5, 2.
} 